DOI: https://doi.org/10.47405/mjssh.v5i10.510

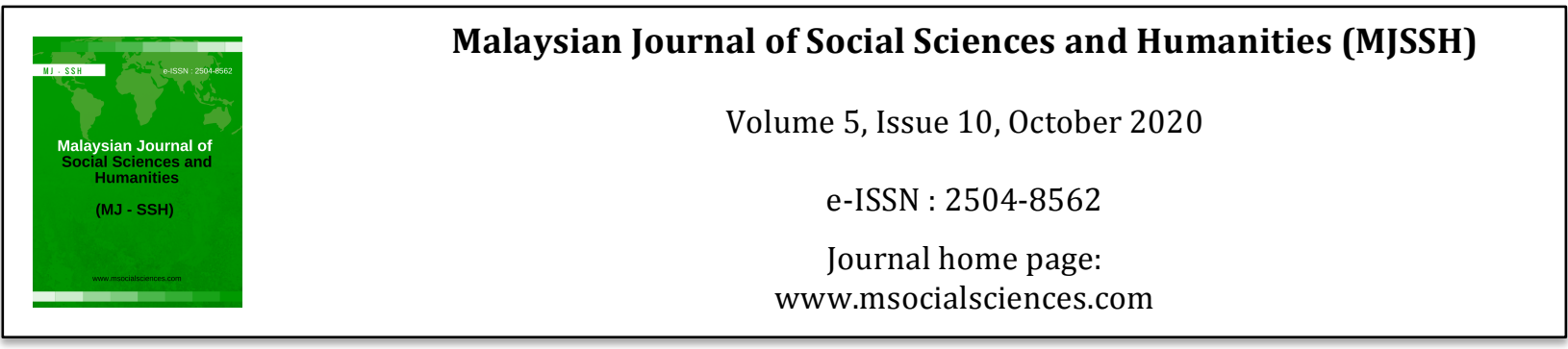

\title{
Persediaan Rakyat Malaysia Dalam Merealisasikan Matlamat Revolusi Industri 4.0
}

\author{
Akmal Ariff Jamhari', Siti Hajar Abd Razak', Nur Anis Karim Mohamad', \\ Mohamad Izzuan Mohd Ishar ${ }^{2}$ \\ ${ }^{1}$ Fakulti Sains, Universiti Teknologi Malaysia (UTM) \\ ${ }^{2}$ Sekolah Pendidikan, Fakulti Sains Sosial dan Kemanusiaan, Universiti Teknologi Malaysia (UTM) \\ Correspondence: Siti Hajar Abd Razak (hajarabdrazak2310@gmail.com)
}

\begin{abstract}
Abstrak
Industri Revolusi 4.0 merupakan antara revolusi yang diambil berat oleh pihak kerajaan. Pakar ekonomi berpendapat bahawa Revolusi Industri 4.0 ini mampu untuk memberi impak yang baik khususnya dalam bidang pendidikan dan bidang pekerjaan di Malaysia. Namun masyarakat Malaysia masih kurang bersedia untuk mendepani cabaran Revolusi Industri 4.0 ini. Oleh itu untuk mencapai tahap kesediaan rakyat Malaysia yang sewajarnya setiap pihak dalam negara perlu mengambil beberapa langkah khusus. Hal ini bagi memastikan masyarakat tahu dan peka terhadap perkembangan Revolusi Industri 4.0 yang sedang berlaku di Malaysia. Untuk merawat luka kita perlu mengetahui seteruk mana luka tersebut. Oleh itu, objektif kajian adalah untuk meneliti tahap persediaan Malaysia menghadapi Revolusi Industri 4.0 pada masa sekarang. Selain itu, mengetahui perkara yang perlu ada dan dilakukan untuk menjadikan Malaysia sebuah negara yang bersedia menghadapi Revolusi Industri 4.0. Metodologi kajian yang akan digunakan adalah melalui sesi temubual. Kajian ini akan dijalankan ke atas pihak berkaitan seperti pihak industri pembinaan, pensyarah dan masyarakat umum. Hasil mendapati masyarakat Malaysia masih kurang pendedahan terhadap Revolusi Industri 4.0 ini. Hal ini membuktikan bahawa banyak inisiatif yang perlu dilakukan oleh semua pihak. Antara langkah yang boleh diambil oleh pihak kerajaan dalam mendepani Revolusi Industri 4.0 ialah menyediakan latihan kemahiran dalam pengendalian teknologi baru dengan kerjasama daripada pihak industri. Seterusnya mampu memberi kesediaan minda dikalangan kakitangan pekerja pada masa akan datang.
\end{abstract}

Kata kunci: revolusi industri 4.0, kesediaan, kerajaan

\section{Preparation of Malaysians in Realizing the Goals of the Industrial Revolution 4.0}

\begin{abstract}
The industry of Revolution 4.0 was one of the revolutions taken by the government. Economists argue that the Industrial Revolution 4.0 capable to make a positive impact especially to the Education and employment in Malaysia. Unfortunately, the Malaysian is still not ready to meet the challenges of the Industrial Revolution 4.0. Therefore, to reach the level Malaysians each party in the country should take certain steps. This is to keep the public informed and aware about the developments of the Industrial Revolution 4.0 in Malaysia. To treat a wound we need to know how bad the wound is. Therefore, the objective of this study is to examine the level of readiness of Malaysia for the current Industrial Revolution 4.0. In addition, knowing what needs to be done will make Malaysia a country ready for the Industrial Revolution 4.0. The methodology of the study to be used is through an interview session. This study will be carried out on related parties such as the construction industry,
\end{abstract}


lecturers and the general public. The results show that the Malaysian public still lacks exposure to the Industrial Revolution 4.0. This proves that many initiatives need to be taken by all parties. One of the steps governments can take in leading the Industrial Revolution 4.0 is to provide skills training in handling new technologies in collaboration with industry. Next, it is possible to provide mindfulness among future employees.

Keywords: industrial revolution 4.0, preparation, government

\section{Pengenalan}

Gelombang revolusi dalam perindustrian iaitu kini dikenali dengan Revolusi Industri 4.0 (IR 4.0), telah mendominasikan teknologi dan mengambil alih peratusan besar dalam kehidupan manusia. Setiap manusia dari pelbagai negara yang maju ataupun yang sedang membangun berusaha bermandi keringat untuk berdaya saing antara satu sama lain untuk memajukan diri sendiri, agama, bangsa dan negara masing-masing, dari segi teknologi terutamanya bagi menjadi platform yang akan digunakan oleh generasi sekarang dan juga generasi akan datang. Revolusi Industri 4.0 memainkan peranan yang amat besar dan penting dalam memacu dan meneruskan hidup umat manusia bagi selari dengan arus teknologi yang kian membangun ini. Kesinambungan daripada revolusi industri yang terdahulu iaitu perubahan dalam automasi, penciptaan komputer, pertukaran data dan maklumat, robot pintar dan segalanya yang berkaitan dengan pembaharuan teknologi realiti maya, sedikit sebanyak telah memberi kesan terhadap aspek kehidupan manusia. Cara kehidupan manusia kini dilihat telah berubah dengan adanya teknologi yang membangun dengan amat pesat sebagai contoh telefon pintar yang setiap masa mempunyai penambah baik yang tersendiri yang digunakan oleh hampir semua lapisan masyarakat dan tidak ketinggalan kepada rakyat Malaysia. Menurut Profesor Bersekutu Dr Sawal Hamid Md Ali, seorang pensyarah kanan di Jabatan Kejuruteraan Elektrik, Elektronik dan Sistem di Universiti Kebangsaan Malaysia (UKM), Revolusi Industri 4.0 adalah sistem mengenai siber-fizikal yang boleh menghubungkan dunia digital dengan sistem biologi seperti manusia iaitu perhubungan dengan internet. Beliau juga turut berpendapat bahawa terdapat hubungan dua hala antara manusia dan elektronik. Hal ini dapat dilihat dengan kebergantungan manusia terhadap telefon pintar, TV pintar serta rumah pintar yang wujud dalam pasaran dunia sekarang.

Walaubagaimanapun, kenyataan daripada media sering kali hanya memperaksikan kemewahan dan kecanggihan sesuatu peralatan teknologi baru itu, akan tetapi adakah masyarakat sedar bahawa apabila seluruh dunia mula memperkasakan industri revolusi 4.0 ini, pasti mempunyai kelemahan kepada sesetengah masyarakat walaupun seiring juga memberi kebaikan kepada sesetengah kelompok masyarakat yang lain. Pelbagai permasalahan yang sedang berlaku masih lagi tidak menunjukkan cakna kepada manifestasi Industri 4.0 malah berkemungkinan cabaran-cabaran baru akan muncul setelah transformasi Industri 4.0 ini dilaksanakan di Malaysia. Bagaimana rakyat mahu menangani masalah isu sosial di kalangan remaja mahupun dewasa? Bagaimana pendidikan mampu diperluaskan kepada pelajar tentang Industri 4.0? Apakah kriteria yang perlu dimiliki untuk memohon pekerjaan yang akan sejajar dengan Industri 4.0 ini?

\section{Objektif}

Tujuan kajian terhadap persediaan Malaysia dalam merealisasikan matlamat revolusi industri 4.0 ialah:

i. Meneliti dan mengkaji tahap persediaan yang telah dilakukan Malaysia dan rakyat menghadapi revolusi industri 4.0 buat masa sekarang.

ii. Mengkaji persediaan secara global (luar negara) terhadap revolusi indusrti 4.0 yang perlu diikuti oleh Malaysia. 


\section{Kajian Literatur}

Matlamat Revolusi Industri 4.0 telah mula diperkenalkan sejak pada tahun 2011 lagi. Pelbagai penghasilan teknologi baru pada tahun demi tahun telah mula dicipta menerusi sembilan teras Industri 4.0 (Rajah 1). Berdasarkan transformasi revolusi industri daripada kerajaan di seantero dunia,sembilan teras Industri 4.0 yang dipersetujui ialah Robot Automasi(Autonomous Robot),Internet saling berhubung(IoT), Data Besar (Big Data), Simulasi (Simulation), Pembuatan Tambahan (Additive Manufacturing), Augmented Reality (AR), Pengkomputeran Awan (Cloud Computing), Sistem Integrasi (Integration System) dan Keselamatan Siber (Cybersecurity).

Rajah 1: Sembilan Terus Industri 4.0

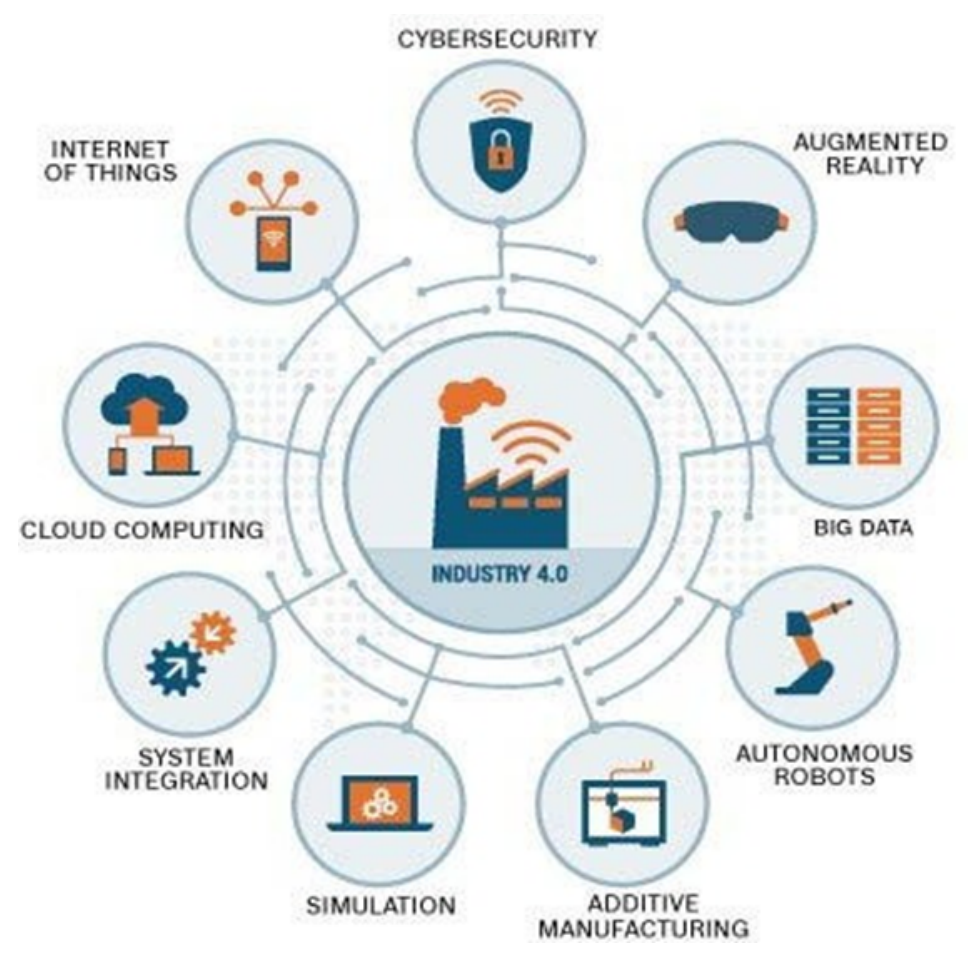

Semua sembilan teras ini adalah merupakan teknologi canggih yang akan mendominasikan kemajuan dalam perindustrian sesebuah negara malah memberi cabaran baru dalam menstabilkan ekonomi negara. Tranformasi ini telah memberikan dorongan kepada syarikat termasuk sektor perkilangan untuk mengaplikasikan teknologi baru ini bagi meningkatkan produktiviti dalam perindustrian dan perkilangan mereka.

Berdasarkan maklumat yang diberikan oleh penulis buku The Fourth Industrial Revolution telah menyatakan bahawa penciptaan robotik yang pertama telah diaplikasikan dalam bidang perubatan di Amerika Syarikat. Oleh hal yang demikian, ini telah mendorong kepada sektor dan bidang lain untuk menggerakkan manifestasi dalam penggunaan robotik untuk bidang pekerjaan masing-masing seperti contoh dalam sektor pertanian. Selain itu, menurut Jay,Behrad dan Huang-An(2014) telah berpendapat bahawa Big Data akan memainkan peranan yang amat penting dalam persaingan perniagaan mereka dimana ianya berfungsi untuk meyimpan dan mengumpul data yang bersaiz besar seperti maklumat syarikat, keluar-masuk kewangan syarikat dan sebagainya. Di samping itu juga, keperluan Internet untuk berhubung bukanlah suatu perkara yang asing kepada masyarakat. Rangkaian internet membolehkan sesebuah robot atau mesin itu melakukan pekerjaannya mengikut kehendak yang telah diprogram. Kesemua itu amat penting bagi mencapai tahap kepintaran sesuatu teknologi sehingga akan wujudnya rumah pintar, kilang pintar, telefon pintar dan sebagainya. 
Pihak kerajaan adalah merupakan tonggak utama dalam kemajuan negara dari segi ekonomi mahupun sosial. Usaha kerajaan mengubah struktur kepada yang lebih baik dan berfikiran kehadapan khususnya dalam pendidikan dapat melahirkan modal insan yang berkemahiran. Tujuh aspek kemahiran insaniah yang perlu dipelopori oleh kesemua pelajar mahupun graduan yang akan menempatkan diri ke alam pekerjaan ialah kemahiran kepimpinan, kemahiran bekerja sepasukan, kemahiran berkomunikasi, kemahiran keusahawanan, pembelajaran berterusan, pemikiran yang kritis dan kemahiran menyelesaikan masalah, etika dan moral profesional. Justeru itu, Pelbagai inisiatif yang perlu dilaksanakan bagi melahirkan individu yang sesuai dalam era revolusi industri 4.0 ini agar kriteria yang diperlukan dalam alam pekerjaan yang diselebungi denga sistem robotik nanti sesuai dengan pelaksanaannya.

Untuk membuat persediaan yang lebih lengkap dan lebih maju kita perlu tahu bentuk-bentuk teknologi yang kian membangun dan memainkan peranan yang amat tinggi dalam pelaksanaan revolusi industri ke-4. Merujuk jadual di bawah daripada buku 'The 4th Revolution Industry and the Future of Job' oleh Nick H.M van Dam.

Jadual 1: Bentuk dan kesan teknologi

\begin{tabular}{lll}
\hline \multicolumn{1}{c}{ Bentuk Teknologi } & \multicolumn{1}{c}{ Kesan terhadap teknologi } \\
\hline $\begin{array}{l}\text { Internet Mudah Alih- Pengkomputeran } \\
\text { mudah alih menggunakan sambungan } \\
\text { internet }\end{array}$ & $\begin{array}{l}\text { Sebanyak } 4.3 \text { bilion orang bergantung } \\
\text { terhadap penggunaan internet mudah } \\
\text { alih }\end{array}$ \\
& $-\begin{array}{l}1 \text { bilion transaksi dan interaksi dalam } \\
\text { bekerja hampir } 40 \% \text { penggunaannya } \\
\text { untuk tenaga kerja }\end{array}$ \\
$\begin{array}{l}\text { Automasi Kerja } \\
\begin{array}{l}\text { Berpengetahuan- Perisian } \\
\text { pintar berkemampuan } \\
\text { menjalankan tugas. }\end{array}\end{array}$ & $\begin{array}{l}230 \text { juta pekerja berpengetahuan. } \\
1.1 \text { bilion pengguna telefon pintar berpotensi } \\
\text { menggunakan aplikasi bantuan kerja secara } \\
\text { digital. }\end{array}$
\end{tabular}

Internet - Rangkaian untuk mengumpul data, pemantauan, membuat keputusan dan pengoptimuman proses.

Teknologi 'cloud'- Sumber perkakas dan perisian dihantar melalui rangkaian atau internet.

Robot pintar

Autonomi - Kenderaan tanpa pengendali

Pengstoran tenaga

Pencetakan 3D- Teknologi pembuatan berpandukan model digital.

Teknolgi Bahan - Bahan yang mempunyai ciri-ciri yang lebih baik.
- 1 trilion benda boleh disambung dengan internet.

- 100 juta mesin yang disambung merentasi negara seperti pengangkutan.

- 2 bilion pengguna 'cloud-base email' seperti Gmail.

- 320 juta kerja pembuatan dan 250 juta pembedahan utama memerlukan bantuan robot pintar

- 1 bilion kereta dan trak.

- 450000 penggunaan kenderaan udara.

- 1.2 bilion manusia tiada punca kuasa elektrik

- 320 juta kerja pembuatan.

- 8 bilion alat permainan dibuat secara global

- 7.6 juta penggunaan silikon

- 450000 penggunaan karbon fiber 

DOI: https://doi.org/10.47405/mjssh.v5i10.510

\begin{tabular}{lll} 
Teknologi pencarian Minyak dan Gas & -22 bilion tong minyak dan gas dihasilkan \\
& secara global \\
Tenaga boleh diperbaharui & $-21000 \mathrm{TWh}$ penggunaan elektrik setiap tahun \\
& -13 bilion penghasilan karbon dioksida hasil \\
& daripada penjanaan tenaga. \\
\hline
\end{tabular}

Setelah meneliti satu persatu bentuk-bentuk teknologi yang perlu dimajukan, kita boleh ambik iktibar dan sedar bahawa banyak lagi usaha yang perlu dibuat untuk memajukan negara kita dalam konteks teknologi. 11 bentuk teknologi yang ada dalam jadual ini telah banyak dimajukan oleh negara luar tetapi kita sebagai rakyat Malaysia perlu sedar bahawa kemajuan teknologi tiada penghujungnya maka kita juga haruslah melibatkan diri dalam memajukan teknologi negara kita ini.

\section{Metodologi}

Kaedah kajian yang akan dijalankan berpandukan seperti yang disenaraikan mengikut peringkat.

\section{Peringkat 1: Kajian awal}

Kajian awal merupakan persediaan mencari isu dan permasalahan yang berlaku. Kajian awalan turut merujuk kepada sumber yang digunakan sebagai bahan kajian seperti buku, jurnal, artikel dan keratan akhbar yang seterusnya digunakan sebagai bahan kajian untuk mengenal pasti masalah. Dalam peringkat ini juga membolehkan untuk mengenal pasti masalah, menyenaraikan objektif untuk mencapai matlamat kajian. Skop kajian juga dikenal pasti bagi memudahkan pencarian data dan maklumat.

\section{Peringkat 2: Pengumpulan data}

Pada peringkat ini lebih kepada penumpuan untuk mengumpul data. Kajian ini menggunakan kaedah temubual kepada responden yang berpotensi. Responden terdiri daripada pihak-pihak yang terlibat dalam industri dan sektor pendidikan.

\section{Peringkat 3: Analisis Data}

Peringkat ini diperlukan untuk menganalisis data yang diterima dengan melalui tiga proses iaitu penyusunan data, analisis data dan persembahan data. Proses penyusunan data adalah berbentuk jadual. Analisis data adalah proses untuk menganalisis data berdasarkan jawapan temubual bersama responden yang dijadualkan berserta dengan pembinaan tema mengikut kata kunci yang terdapat dalam jawapan tersebut.

\section{Peringkat 4: Rumusan dan Cadangan}

Pada peringkat ini hasil dapatan kajian akan dirumuskan berdasarkan penilaian dan mengambil kira pendapat responden. Seterusnya akan menjadikan itu sebagai rujukan bagi memberi cadangan. Permasalahan yang dihadapi sepanjang menjalankan kajian turut dinyatakan. Seterusnya kajian lanjutan boleh dicadangkan sebagai penyambung kepada objektif lain yang berpotensi.

\section{Analisis Kajian}

Analisis dilakukan adalah berdasarkan daripada soalan-soalan yang terdapat dalam transkrip temubual. Kajian ini dijalankan bagi mencapai objektif kajian iaitu : 
i. Meneliti dan mengkaji tahap persediaan yang telah dilakukan Malaysia dan rakyat menghadapi Revolusi Industri 4.0 buat masa sekarang.

ii. Mengkaji persediaan secara global(luar negara) terhadap Revolusi Industri 4.0 yang perlu diikuti oleh Malaysia.

Terdapat seramai 9 orang responden yang telah ditemubual. Antaranya adalah golongan yang bekerja dalam industri, guru, pelajar IPT, dan pelajar sekolah dimana terdiri daripada lingkungan umur yang berbeza. Berdasarkan transkrip temubual, terdapat 6 soalan diajukan kepada responden. Salah satu soalan telah dibahagikan kepada golongan yang sudah bekerja dan juga pelajar.

Pembinaan tema daripada kajian kualitatif ini bersangkut-paut dengan kata kunci yang terdapat daripada jawapan responden. Berdasarkan perbualan ini terdapat sebanyak 9 tema yang berkait dengan jawapan yang diberikan oleh responden (Jadual 2).

Jadual 2: Senarai Tema dan Makna

\begin{tabular}{ll}
\hline Tema & Makna \\
\hline Global & Dari sudut negara lain \\
Revolusi & Perubahan dari zaman dahulu hingga kini \\
Teknologi & Teknologi yang tercipta berkaitan dengan Industri Revolusi 4.0 \\
Kesedaran & Kesedaran responden tentang IR4.0 \\
Langkah Persediaan & Persediaan responden dalam menghadapi Revolusi Industri 4.0 \\
Pandangan & Sudut pandangan responden tentang IR4.0 di Malaysia \\
Penyertaan & Penglibatan dalam era Industri 4.0 \\
Pengetahuan & Ilmu tentang Industri 4.0 \\
Motivasi / Demotivasi & Elemen positif tentang Industri 4.0 \\
& Elemen negatif tentang Industri 4.0 \\
\hline
\end{tabular}

\section{Soalan dan Jawapan Temu Bual Bersama Responden}

Setelah mengkaji beberapa jawapan responden, 6 orang daripada 9 responden mengetahui tentang kewujudan manifestasi Revolusi Industri 4.0 dan kesemua responden telah mengakui bahawa mereka menyedari dan dapat merasai era perkembangan revolusi industri yang berlaku di dunia kini.

Berdasarkan soalan kajian yang pertama "Apakah peringkat revolusi industri yang kini hangat diperkatakan di negara Malaysia yang sedang membangun ini?" berikut merupakan perbincangan dapatan analisis. Dapatan soal selidik mendapati 6 daripada 9 responden mnegetahui bahawa negara sedang menghadapi revolusi industri 4.0 dan 3 daripadanya menyatakan mereka tidak mengetahui. Responden yang tidak mengetahui itu adalah dari kalangan pelajar dan guru yang berumur lebih dari 50 tahun. Ini menunjukkan bahawa masyarakat tahu akan revolusi industri di Malaysia. Namun masih ada yang tidak mengetahui kerana mereka kurang mendapat pendedahan.

Soalan kajian kedua "Sedalam manakah pengetahuan anda tentang revolusi industri yang terkini?" Hasil dapatan soal selidik mendapati pengetahuan tentang revolusi bergantung kepada pekerjaan dan bidang pelajaran yang diambil. Sekiranya pekerjaan berkait rapat dengan industri revolusi maka pengetahuan mereka lebih banyak dan mampu untuk menjelaskan dengan lebih baik. Mereka juga mampu untuk memberi perbezaan antara revolusi industri terdahulu dengan masa kini. Sebagai contoh seorang responden memberitahu tentang teknologi 5G yang merupakan salah satu cabang perkembangan dalam revolusi industri 4.0.

Seterusnya untuk soalan kajian ketiga "Adakah anda menyedari bahawa pada masa akan datang, negara Malaysia akan dikejari dengan penciptaan robot yang akan mengambil alih dalam industri?”. Semua responden sedar akan perkara tersebut. Mereka mendapat pendedahan melalui media sosial dan juga kawasan sekitar mereka. Bagi mereka yang masih belajar mereka mendapat pendedahan di 
tempat belajar. Bagi responden yang bekerja mereka mendapat pendedahan dari tempat kerja mereka yang mana penggunaan teknologi seperti robot bakal dilaksanakan.

Soalan keempat kajian "Apakah inisiatif ke arah kemajuan ataupun perubahan dalam teknologi perindustrian yang anda lihat dalam sektor pekerjaan anda?. Bagi responden yang telah bekerja mereka berkata di tempat kerja mereka pelbagai inisiatif telah dilakukan untuk seiring dengan revolusi industri 4.0. Antara yang dilakukan adalah dari segi pengurusan kerja. Banyak kerja dilakukan melibatkan teknologi. Sebagai contoh dalam sektor pendidikan para guru digalakkan untuk menggunakan teknologi yang disediakan seperti 'smart whiteboard' di sekolah bagi menjadikan sesi pembelajaran itu lebih menarik dan memudahkan. Bagi pekerjaan yang melibatkan pembaikan perpaipan, teknologi 'drone' digunakan untuk melihat bahagian yang sukar untuk dilihat bagi memastikan tiada kerosakan yang berlaku.

Soalan kelima kajian "Apakah persediaan anda jika anda didapati terpaksa dibuang kerja akibat daripada kuasa revolusi industri ini? Menurut responden isu ini sukar berlaku kerana kebanyakkan majikan akan memastikan kebajikan pekerja mereka. Namun sekiranya hal itu berlaku apa yang akan dilakukan adalah mengambil tahu tentang revolusi terkini dan cuba untuk memenuhi kriteria yang perlu dalam industri. Selain daripada itu perlu kepada adaptasi dengan cepat segala perubahan yang perlu bagi memastikan mereka kekal relevan dalam bidang mereka.

Soalan keenam kajian "Pada pendapat golongan pelajar, jika pihak sekolah mahupun universiti mengadakan sesuatu pertandingan inovasi, teknologi mahupun pertandingan robotik, adakah anda mempunyai semangat untuk menyertai pertandingan tersebut dan adakah anda merasakan bahawa inisiatif itu penting untuk menambah pengetahuan anda?. Bagi soalan ini berkaitan dengan para pelajar. Kebanyakkan responden yang terdiri daripada pelajar merasakan inisisatif yang dilakukan oleh kerajaan terhadap perkembangan industri revolusi ini adalah perlu. Ini juga membantu mereka untuk menghadapi revolusi industri apabila mereka bekerja kelak. Segala pertandingan yang dianjurkan juga mampu untuk mencungkil bakat dan memberi pendedahan kepada mereka mengenai revolusi industri 4.0.

\section{Kesimpulan dan Cadangan}

Secara keseluruhannya, kajian ini dapat disimpulkan bahawa tahap persediaan Malaysia khususnya golongan rakyat dalam merealisasikan Industri 4.0 masih belum mencapai 100\% keyakinan terhadap matlamat ini terutama sekali pada golongan pelajar sekolah. Kementerian kerajaan dan peranan pihak sekolah sememangnya digalakkan untuk mendedahkan ilmu teknologi ini kepada pelajar agar di peringkat universiti mahupun di alam pekerjaan kelak akan lebih bersedia untuk berdepan dengan Industri Revolusi 4.0 dimana ianya mementingkan penciptaan robotik. Walaupun daripada perspektif global iaitu kemajuan industri di negara maju seperti negara China,Jepun mahupun Amerika Syarikat sudahpun mula menjalankan aspirasi ini secara keseluruhannya akan tetapi Malaysia masih belum terlambat dalam kesedaran ini. Cuma perlu diusaha bagi melahirkan generasi yang cemerlang dan berdaya saing. Pelbagai cabaran seperti masalah ekonomi dan sosial masih lagi diperingkat yang membimbangkan. Maka dengan itu, kesemua golongan rakyat,pihak kerajaan mahupun swasta perlu sedar dan bangkit untuk berdepan dengan realiti dunia tentang Industri Revolusi 4.0.

Terdapat beberapa permasalahan berlaku semasa kajian dilaksanakan iaitu penghad status responden yang hanya boleh ditemubual hanya di sekitar yang terdekat sahaja. Oleh hal disebabkan itu, kajian ini kurang mendapatkan responden yang benar-benar berpotensi untuk menceritakan ilmunya dengan lebih terperinci tentang Industri Revolusi 4.0 . Selain itu juga, masalah yang dihadapi oleh sesetengah responden untuk menjawab soalan yang diberikan kerana kurang pengetahuan tentang Revolusi Industri 4.0 akan tetapi mereka dapat menjelaskan perkembangan revolusi industri yang terdahulu. Antara cadangan kajian lanjutan yang boleh diketengahkan adalah tentang pencapaian UTM dalam dunia robotik. Oleh disebabkan matlmat sebenar Industri 4.0 ini amat mementingkan teknologi robotik, sudah sememangnya langkah persediaan daripada Institut Pengajian Tinggi (IPT) perlu 
memberi tanggapan yang baik kepada penggerak negara supaya Malaysia juga berkebolehan untuk menjadi negara yang diiktiraf dalam bidang teknologi ini.

\section{Rujukan}

Abdul Rahman Talib, A. (2019). Keberkesanan latihan TVET dan bantuan modal peralatan kepada golongan asnaf fakir dan miskin dalam peningkatan pendapatan di negeri Pahang. Jurnal Dunia Pengurusan, 1(1), 10-17. Didapatkan dari http://myjms.moe.gov.my/index.php/jdpg

Dam, N. (2017). The 4th industrial revolution \& the future jobs. bookboon.

Eznieka, N. (2019)Revolusi industri 4.0 di Malaysia.

Ghislieri, C. (2018). Work and Organizational Psychology looks at the fourth industrial revolution: how to support workers and organizations? Frontiers. Retrieved from https://doi.org/10.3389/fpsyg.2018.02365

Hassan, P. M. (2019). Jenamakan TVET dengan acuan kita. Didapatkan dari https://www.bharian.com.my/

Makhbul, Z. K. (n.d.). Mengurus modal insan dalam industri 4.0. Journal of Social Sciences and Humanities, 3.

Mohamad Fadli Shafiei, N. (2019). Kepimpinan dalam era revolusi industri 4.0. Jurnal Dunia Pengurusan, 3-5. Didapatkan dari http://myjms.moe.gov.my/index.php/jdpg

Parid, W. (2019). Sejauh manakah revolusi industri 4.0 boleh meningkatkan keberkesanan sistem perkhidmatan awam? ResearchGate. Didapatkan dari https://www.researchgate.net/

Salam, P. D. (n.d.). UTeM santuni keperluan pembelajaran era revolusi industri 4.0. Melaka: Pusat Sumber \& Teknologi Pengajaran, UTeM (PSTP).

Suparman, F. (2018). Revolusi Industri 4.0. Didapatkan dari https://upm.edu.my/

Xing, B. (2017). Implications of the fourth industrial age for higher education. Xing, Bo and Marwala, Tshilidzi, Implications of the Fourth Industrial Age for Higher

The_Thinker Issue_73 Third_Quarter_2017. Didapatkan dari Xing, Bo and Marwala, Tshilidzi, Implications of the Fourth Industrial Age for Higher Education (201 https://ssrn.com/abstract=3225331

Yoon, D. (2017, April 30). What we need to prepare for the fourth industrial revolution. 